\title{
Umbilical Cord Blood Donation and Banking: Awareness Among Pregnant Women, in Makurdi, Nigeria
}

\author{
Nwannadi Ikenna Alexander, Alao Olusayo Olayinka, Swende Terrumun, \\ Elachi Adaoje Felix
}

\begin{abstract}
Background: Umbilical Cord Blood (UCB) donation and banking is transforming transfusion medicine around the world. There is a dearth of data on awareness and perception of this practice among pregnant women in our setting.

Objectives: We sought to determine the awareness of UCB donation and banking by pregnant women in Makurdi, North central, Nigeria.

Methods: With the use of structured questionnaire, information on socio-demography, awareness of UCB donation and banking, and sources of information on UCB were collected from 302 pregnant women attending the antenatal clinic of Benue State University Teaching Hospital, Makurdi. Data generated was analyzed with Statistical Package for Social Sciences version 19.

Results: Majority of the respondents was aged 25-30 years (52.0\%). They were predominantly Tiv (84.2\%), Civil servants (45.3\%), Christians (95.1\%), and 62.4\% had tertiary education. Nineteen percent of the women were aware of UCB donation and banking. The sources of information on UCB were hospital (30.2\%), media (39.0\%), friends, (24.0\%), the internet (6.8\%). Awareness of UCB as an alternative to adult blood transfusion was not influenced by socio-demographic characteristics of the respondents.

Conclusion: Awareness of UCB donation and banking by pregnant women in Makurdi is low. The major source of information on UCB was from the media. Public awareness programs will have to be instituted especially in the health facilities. These programs if properly implemented will improve the willingness of pregnant women to donate UCB and also enhance the acceptance of UCB as a treatment option.
\end{abstract}

\section{Introduction}

The practice of Umbilical cord blood (UCB) donation and banking is increasingly being practiced in many parts of the world.1,2 In Nigeria, the demand for blood and blood products far outweigh supply.3 The current practice is a dependence on relatives, friends or paid donors. With a population of about 160 million, 4 just over 36,200 units of whole blood were collected in 2010 by the National Blood Transfusion Service (NBTS).5 As at 2005, an estimated 1,500,000 unit were needed by Nigerians.6 Nigeria is far from the WHO recommendation as her whole blood donations (units) per 1,000 population stands at 0.2.7 Paid (unsafe) donors still make up large percentage of blood donations in the public and private health facilities. The challenge of unavailability of blood in our health facilities is enormous. One way of addressing this is to consider the use of UCB as treatment and transfusion option to Nigerians. The key to improving the willingness to donate UCB and the acceptance of UCB as treatment option depends on the awareness of the usefulness of UCB to the public. We therefore explored the awareness level of this practice among pregnant women in Makurdi, Nigeria.

\section{Materials And Methods}

This study was approved by the ethics review board. It was a cross sectional study carried out in a tertiary hospital in Nigeria. The population of study comprised pregnant women attending the antenatal clinic of the hospital. The sample size as calculated with the Yaro-Yamen's formula was 302. Non-pregnant females were excluded from the study. The instrument for data collection was structured questionnaire which was pretested and all ambiguous questions restructured for easier understanding. The questionnaire had an internal consistency of 0.72 Cronbach's alpha and is therefore suitable for the study. The questionnaire was administered to the subjects by the clinic nurse and it takes an average of five to seven minutes to complete. Information on sociodemography, awareness of use of UCB donation and banking, and source of information on UCB were collected from the respondents. The 302 questionnaires were duly completed and were used for analysis. Data generated was analyzed with Statistical Package for Social Sciences version 19. Results were presented in percentages. The association of socio-demographic factors and awareness of use of UCB donation and banking was tested with the chi-square test. 


\section{Results}

Majority of the respondents was aged 25-30 years (60.1\%). They were predominantly Tiv (84.2\%), Civil servants (45.3\%), Christians (95.1\%), primigravida (39.4\%) and with tertiary education (62.4\%). Table 1 . Table 1; Socio-demographic characteristics of the respondents.

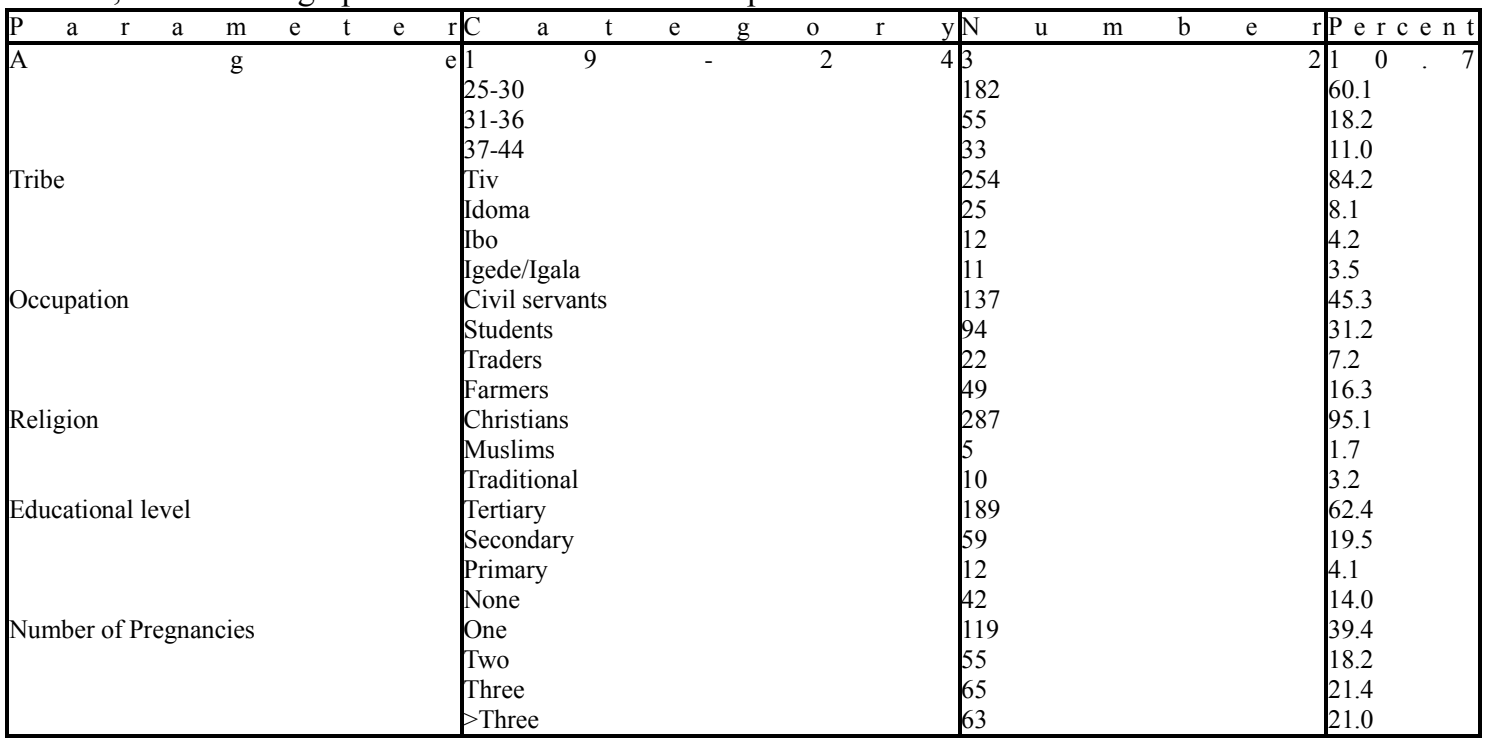

Nineteen percent of the women were aware of UCB donation and banking. Table2.

Table 2; Response of the respondents to the questions "Are you aware of UCB donation and banking."

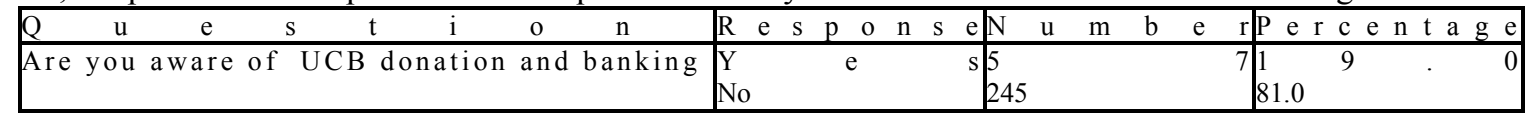

The sources of information on UCB were hospitals (30.2\%), media (39.0\%), friends, $(24.0 \%)$, and the internet (6.8\%). Awareness of UCB donation and banking was neither influenced by socio-demographic characteristics nor number of pregnancies of the respondents.

\section{Discussion}

The supply of safe and quality blood for transfusion in health facilities in Nigeria is inadequate. As a result, we must begin to consider other alternatives to voluntary blood donation. One of such alternatives is umbilical cord blood (UCB) which is readily available. The practice of UCB donation and banking is on the increase in many parts of the world. Since 1988 when the first UCB was used for treatment, 8 more than 6,000 unrelated donor cord-blood transplants have been done in 150 locations worldwide. 9 Cord blood transplants have been recommended and performed for a variety of diseases including leukaemias, lymphomas, sarcomas, immune deficiencies, and some metabolic disorders.10-14 An average of about $100 \mathrm{ml}$ of blood can be harvested from a placenta, and in Nigeria about 5 million children are born annually (UNICEF Nigeria 2007). This amounts to about $500,000,000 \mathrm{ml}$ of blood wasted on annual basis. If UCB is put to use in Nigeria, it will become a major relieve to the issue of shortage of blood. Cord blood is collected by an obstetrician or other licensed practitioner, either before or after delivery of the placenta. "In utero" collection is performed after delivery of the newborn but before delivery of the placenta, "ex utero" after the delivery of the placenta.15 In both methods, the umbilical cord is clamped at one end, a needle is inserted into the umbilical vein on the unclamped end, and the blood is allowed to flow through the needle into a collection bag .16 The success of UCB donation and banking depends heavily on the level of awareness of the benefits of UCB among pregnant women who are to donate the cord blood. Awareness will impact positively on their willingness to donate UCB and on their acceptance of UCB as treatment option. Awareness of this type of transfusion and its benefits will improve the willingness to donate $\mathrm{UCB}$ and also to accept it as an alternative to adult blood and as a treatment option for a number of inherited and acquired medical conditions.

The awareness of UCB donation and banking in this study was $19.0 \%$. This contrasted with $63.0 \%$ that was recorded among patients in Arizona, United States of America.17 In the US study, $74 \%$ described themselves as minimally informed, $2.6 \%$ described themselves as extremely knowledgeable, $45 \%$ of patients were unaware of the potential for cord blood use by a sibling and $14 \%$ of patients were educated by their 
healthcare provider on cord blood banking. Similar published studies conducted in other countries 18 have shown the majority of surveyed women had little knowledge of cord blood banking and donation. The majority of those surveyed would choose to donate their infant's umbilical cord blood if given the opportunity. For instance, in a study in Turkey, 18 only $26 \%$ of surveyed women had information or knowledge about cord blood banking and donation. In that same study $74 \%$ of women would donate to a public bank if given the opportunity. These awareness levels though low, are however higher than the 19\% recorded in our study. The reason for the very low awareness in our study is as a result of the absence of UCB donation and banking in our country. Unlike in Nigeria, some other developing countries are already practicing UCB donation and banking.19-21 However awareness of this practice among pregnant women in these countries has not been widely reported.

Analysis of the source of information on UCB showed that media was the major source of knowledge on UCB donation and use. This is because the hospital for study has not commenced the practice of UCB donation and banking so there was no need to educate the women on the use of this product.

\section{Conclusion;}

The level of awareness of UCB donation and banking by pregnant women in Makurdi is low. Every pregnant woman should be educated about the benefits of Umbilical cord blood donation and banking as this is central to the success of UCB donation and banking in the country.

\section{Acknowledgements}

We acknowledge the support of the staff of the antenatal clinic of the Benue State University Teaching Hospital.

Disclosure of interests

We have no conflicts of interest to disclose

\section{Contribution to authorship}

The authors have all contributed in conception of the research topic, data collection, analysis, result interpretation and drafting of the Manuscript

\section{Details of ethics approval}

This study was approved by the institutional ethic review board.

Funding- None

\section{References}

[1]. Gluckman E, Broxmeyer HE Auerbach AD Hematopoietic reconstitution in a patient with Fanconi's anemia by means of umbilical cord blood from an HLA-identical sibling. 1989 N Engl J Med 321 : 1174-1178

[2]. Wagner JE, Kernan NA, Steinbuch M, et al. Allogeneic sibling cord blood transplantation in forty four children with malignant and non malignant disease. 1995 Lancet $346: 214-219$ http://www.unicef.org/nigeria/children.htm

[3]. Chioma O. Ignorance, negative attitude, bane of voluntary blood donation. Vanguard newspaper June 04,2013

[4]. UNDP. 2010. 2010 revision of the United Nations Population Division census estimates. http://esa.un.org/unpd/wpp/unpp/panel_profiles.htm(accessed 13.06.13)

[5]. CDC. Progress Toward Strengthening National Blood Transfusion Services - 14 Countries, 2008-2010. MMWR Weekly, 2011: 60(46);1578-1582.http://www.cdc.gov/mmwr/preview/mmwrhtml/mm6046a2.htm

[6]. National Blood Transfusion Service [Nigeria]. 2006. Nigeria National Blood Policy: Revised November 2005. Abuja: National Blood Transfusion Service, Federal Ministry of Health

[7]. World Health Organization. 2009. Blood safety and availability: facts and figures from the 2007 Blood Safety Survey. Geneva: WHO. As cited in CDC. Progress Toward Strengthening National Blood Transfusion Services - 14 Countries, 2008-2010. MMWR Weekly, 2011: 60(46);1578-1582. http://www.cdc.gov/mmwr/preview/mmwrhtml/mm6046a2.htm

[8]. Gluckman E, Broxmeyer HE Auerbach AD Hematopoietic reconstitution in a patient with Fanconi's anemia by means of umbilical cord blood from an HLA-identical sibling. 1989 N Engl J Med 321 : 1174-1178

[9]. Kurtzberg J, Lyerly, Drapkin A, Sugarman J. Untying the Gordian knot: policies, practices, and ethical issues related to banking of umbilical cord blood. J Clin Invest. 2005;115(10):2592-2597.

[10]. Work Group on Cord Blood Banking. Cord Blood Banking for Potential Future Transplantation: Subject Review. Pediatrics. 1999;104(1):116-118.

[11]. Hwang WY, Samuel M, Tan D, Koh LP, Lim W, Linn YC. A meta-analysis of unrelated donor umbilical cord blood transplantation versus unrelated donor bone marrow transplantation in adult and pediatric patients. Biol Blood Marrow Transplant. 2007;13:44453. doi: 10.1016/j.bbmt.2006.11.005.

[12]. Frangoul H, Wang L, Harrell FE, Jr, Manes B, Calder C, Domm J. Unrelated umbilical cord blood transplantation in children with immune deficiency: results of a multicenter study. Bone Marrow Transplant. 2010;45:283-8. doi: 10.1038/bmt.2009.137.

[13]. Prasad VK, Mendizabal A, Parikh SH, Szabolcs P, Driscoll TA, Page K, et al. Unrelated donor umbilical cord blood transplantation for inherited metabolic disorders in 159 pediatric patients from a single center: influence of cellular composition of the graft on transplantation outcomes. Blood. 2008;112:2979-89. doi: 10.1182/blood-2008-03-140830.

[14]. Eapen M, Rubinstein P, Zhang MJ, Stevens C, Kurtzberg J, Scaradavou A, et al. Outcomes of transplantation of unrelated donor umbilical cord blood and bone marrow in children with acute leukaemia: a comparison study. Lancet.2007;369:1947-54. doi: 10.1016/S0140-6736(07)60915-5.

[15]. Beckman A, Lubin Bertram H, Greene MF. Collection and storage of umbilical cord blood for hematopoietic cell transplantation. UpToDate. http://www.patients.uptodate.com/topic.asp?file=hcell_tr/10338.

[16]. KidsHealth for Parents. Banking Your Newborn's Cord Blood. Nemours Foundation.

[17]. http://kidshealth.org/parent/pregnancy_newborn/pregnancy/cord_blood.html.

[18]. Perlow JH. Patients' knowledge of umbilical cord blood banking. J Reprod Med. 2006 Aug;51(8):642-8.

[19]. Dinc, H., \& Sahin, N. Pregnant Women's Knowledge and Attitudes about Stem Cells and Cord Blood Banking. International Nursing Review, 2009; 56(2), 250-256. 
[20]. Hassall O, Bedu-Addo G, Adarkwa M, Danso K, Bates I. Umbilical-cord blood for transfusion in children with severe anaemia in under-resourced countries. Lancet. 2003 Feb 22;361(9358):678-9.

[21]. Niranjan Bhattacharya. A preliminary study of placental umbilical cord whole blood transfusion in under resourced patients with malaria in the background of anaemia. Malar J. 2006; 5: 20.

[22]. Bhattacharya N.Placental umbilical cord whole blood transfusion: a safe and genuine blood substitute for patients of the underresourced world at emergency. $J$ Am Coll Surg. 2005 Apr;200(4):557-63. 